\title{
NELFE wt Allele
}

National Cancer Institute

\section{Source}

National Cancer Institute. NELFE wt Allele. NCI Thesaurus. Code C140312.

Human NELFE wild-type allele is located in the vicinity of $6 \mathrm{p} 21.33$ and is approximately 7 $\mathrm{kb}$ in length. This allele, which encodes negative elong ation factor E protein, plays a role in transcript elongation and RNA binding. 